\title{
AN INTRODUCTION TO SERVANT LEADERSHIP AND ITS POTENTIAL FOR NONPROFIT ORGANIZATIONS
}

\author{
Lucian SFETCU1 \\ DOI: https://doi.org/10.35782/JCPP.2021.4.04
}

\begin{abstract}
Most leadership styles are trying to maximize leaders' efficiency in achieving organizational goals, using different approaches. This article makes a short introduction to the concept of servant leadership, a relatively new style of leadership that focuses on addressing followers' needs and supporting them to achieve personal and organizational goals. Servant leaders are authentic, empower and empathize with their followers, empathize with them and show stewardship. This style developed at roughly the same time with the positive ideology and relatively close to the transformational leadership style, a style that is used mainly in organizations that go or are willing to go through a transformational change process. Although servant leadership is an important and resourceful leading style, it is not widely as used and researched as it should, both in for-profit but mostly in nonprofit organizations.
\end{abstract}

Keywords: servant leadership, transformational leadership, authentic leadership, nonprofit organizations.

\section{What is servant leadership?}

Servant leadership is a type of leadership that focuses on supporting employees in achieving their professional or personal goals so that, in turn, they perform at work and help the organization achieve its goals. According to Ehrhart (2004), servant leaders are leaders who place high importance on providing assistance to their subordinates as well as recognizing and anticipating their needs and expectations. This form of leadership looks out for the interests of the leader's followers and takes their well-being into consideration (Laub, 1999). Instead of being worried about the company as a whole, servant leaders are concerned about the people who work alongside them (Adiguzel et al., 2020). Servant leaders do have a strong emphasis on employee development and empowerment and the leader's compassion, empathic engagement, ethical behavior,

1 Assistant Professor, Ph.D., Department of Sociology and Social Work, Faculty of Philosophy and Social-Political Sciences, "Alexandru Ioan Cuza" University of Iasi, e-mail: lucian.sfetcu@gmail.com 
and community management (Greenleaf, 1977; Liden et al., 2008). Greenleaf (1977) further believes that a servant leader has and acknowledges her or his moral responsibility for the organization's success and, likewise, for the success of their subordinates, the organization's stakeholders, and customers.

During the past two decades, positive leadership styles and positive thinking have developed as a unique and acceptable answer to the challenge that conventional management paradigms are striving to resolve. Currently, both academics and practitioners are interested in the notion of servant leadership, which is not surprising given the times we live in (Liden et al., 2008; Sendjaya \& Sarros, 2002).

Servant leadership requires expressing care for and selfless sensitivity to the well-being of followers, as well as developing meaningful, trusting dyadic relationships with followers and maintaining a psychologically safe and equitable work environment (Ehrhart, 2004). Servant leadership inspires followers to participate in activities that have the potential to make a good impact in the lives of others by serving as a centrifugal force that transforms workers' attitudes away from self-interest and toward service (Bauer et al., 2019). It also plays a crucial function in inspiring people to do tasks to assist the firm in accomplishing its objectives (Smith et al., 2004). Additionally, according to other leadership styles, servant leadership is critical for fostering staff cooperation and innovation (van Dierendonck et al., 2014).

According to Akingbola (2013), effective leadership in the nonprofit sector is not very different from that in the public or private sectors, nonprofit organizations needing just a slightly distinct leadership style due to their dependence on contributions and volunteers, focus on purpose over profit, lower pay and limited resources, and competition for skilled leaders with other sectors, among other things (Herman, 2016). Although servant leadership has received little attention in the nonprofit leadership literature (Palumbo, 2016), it has the potential of being a good leadership style fit thanks to its emphasis on mission, and its follower-centric way of reaching organizational objectives (Allen et al., 2018).

\section{History and Development}

Robert Greenleaf (1977) was the first to articulate the servant leadership ideology, which emphasizes the need to place the needs of followers and stakeholders above everything else. According to Greenleaf (1977, p. 7), "the Servant-Leader is servant first... It begins with the natural feeling that one wants to serve, to serve first. Then conscious choice brings one to aspire to lead... The best test, and difficult to administer is this: Do those served to grow as persons? Do they, while being served, become healthier, wiser, freer, more autonomous, and more likely themselves to become servants? And, what is the effect on the least privileged in society? Will they benefit, or at least not further be harmed'. Greenleaf believed that, for a leader to be truly effective, he or she needs to focus on serving others, in most cases, serving her or his followers.

When compared to other leadership styles, a leader who practices servant leadership is truly concerned with the well-being of those under his or her command (Greenleaf, 1977). In addition, Luthans and Avolio (2003) consider that servant leaders are 
50 | An introduction to servant leadership and its potential for nonprofit organizations

motivated by the need to serve more than by the need for power. Hale and Fields (2007, p. 397) used an explanation of servant leadership as being "an understanding and practice of leadership that places the good of those led over the self-interest of the leader, emphasizing leader behaviors that focus on follower development and de-emphasizing glorification of the leader".

In order to conduct empirical research on servant leadership, the researchers and authors in this field realized the need to develop a servant leadership scale based on established psychometric procedures. The scale developed by Liden et al. (2008) captures seven servant leadership dimensions: "putting subordinates first, belping subordinates grow and succeed, empowering, emotional healing, creating value for the community, behaving ethically, and conceptual skills". According to Greenleaf, serving others requires prioritizing their needs, which includes helping subordinates to see and reach their full potential. Another feature of servant leadership outlined by Liden and his colleagues (2008), which is based on Greenleaf's (1977) belief that a servant leader must act in this manner in all parts of life, is helping to generate value for the community that serves as the organization's home, both by directly offering service to the community and by inspiring followers to do the same. As well as finding evidence for the component of fostering ethical conduct through behaving with honesty and integrity, Liden and his colleagues discovered support for another dimension.

Even after controlling for both the leadership model for excellence and transformational leadership, Liden and his colleagues (2008) discovered a positive association between servant leadership, in-role performance, organizational commitment, and community civic behaviors in an organizational field sample, which they used for constructing their servant leadership scale. Leader-member interaction and transformational leadership are distinct from servant leadership, as Ehrhart (2004) identified four years earlier. They also discovered that servant leadership is distinct from transformative leadership.

Ehrhart (2004) wrote one of the early empirical publications on servant leadership. Following a comprehensive review of the literature, he developed a scale based on seven characteristics of servant leadership, which he then tested in cross-sectional research on workers at a grocery store chain. This was shown using a three-factor confirmatory factor analysis, which included components for servant leadership, leadermember exchange, and transformational leadership. This demonstrates that servant leadership is empirically distinct from the other two researched leadership styles. Additionally, Ehrhart identified data establishing a relationship between servant leadership and corporate citizenship practices.

Walumbwa and his colleagues (2010) built on Ehrhart's (2004) results by demonstrating group and individual-level intermediate mechanisms that explain how servant leadership enhances organizational commitment and commitment to others. They conducted longitudinal research using data from seven multinational firms in Kenya, Africa and utilized Ehrhart's (2004) 14-item measure to assess their performance. In their results, they found that servant leadership and organizational commitment were somewhat mediating relationships for procedural fairness and service climate at the group level, as well as for self-efficacy and commitment to supervisor at the individual level. As a means of reducing the influence of individual-level factors on organizational citizenship behavior, the authors advised that procedural fairness and service climate 
should be considered. Even while evidence was found to support the effect of procedural fairness and service environment on the link between commitment to the supervisor and corporate citizenship conduct, no evidence was found to support the influence of any other variables. It is important to highlight that although the authors did not control for leader-member interchange or transformational leadership, in contrast to Ehrhart (2004), the outcomes of this study provide significant support for the theoretical assumptions of servant leadership. A unique expectation of servant leaders is that they will aid their subordinates in evolving into competent members who will, in turn, become servant leaders themselves. According to these results, servant leadership is associated with better levels of self-efficacy and organizational citizenship behavior, as well as settings of justice and service, providing empirical support for this theoretical premise.

Using the 28-item scale established by Liden and his colleagues (2008), Hu and Liden (2011) examined the impact of servant leadership on team potency and openness to change in a sample of five Chinese banks. The study's results support a moderatedmediation model, demonstrating that servant leadership directly improves team effectiveness and that these benefits are partially mediated by team potency. The authors discovered that team potency also acted as a mediator between the effects of goal clarity and process clarity on team effectiveness and effectiveness. As a result of servant leadership's effect on these connections, the relevance of objective and process clarity for team potency has increased. This study found that teams with less clarity about their objectives had better team potency when a servant leader was absent; in other words, it was preferable to lack a clear sense of purpose if the leader did not provide the support associated with servant leadership. As with a servant leader, the link between goal clarity and team potency was strong and positive. Team potency and efficacy were shown to be enhanced by servant leadership, according to the results of the study.

Using the 28-item scale developed by Liden et al. (2008), Schaubroeck and colleagues (2011) undertook cross-sectional research of workers at two separate banks in two different countries with the objective of examining the influence of two distinct leadership approaches in practice. Both service-oriented and transformational leadership styles led to team performance improvement, although in distinct ways. Servant leadership seems to be motivated by service-based trust and greater psychological safety within the team, while transformational leadership appears to be motivated by cognitive trust and increased team capacity. After adjusting for transformational leadership, the research found that servant leadership explained an extra $10 \%$ of the variation in team performance.

Peterson and his colleagues (2012) used a reduced 16-item version of the Liden's scale (Liden et al., 2008) to explore the causes and consequences of servant leadership in 126 technology businesses in the United States of America. They gathered the information over a period of four years. CEO narcissism was shown to be negatively associated with servant leadership, whereas CEO founder status (as opposed to non-founder) was found to be positively associated with servant leadership, according to the findings. Furthermore, even after controlling for transformative leadership, the authors discovered a favorable association between CEO servant leadership and business 
52 An introduction to servant leadership and its potential for nonprofit organizations

success defined as return on assets. This research provides conclusive proof that toplevel servant leadership improves the performance of the whole business and that there is a distinct distinction between servant leadership and transformational leadership, as shown by the findings.

Van Dierendonck (2011) produced a detailed assessment of the literature on servant leadership in which he gave an overview of the concept, offered background information on it, and enumerated and discussed the important components of servant leadership. Then he spoke about the contrasts between servant leadership and the other main leadership paradigms available at the moment. In his conclusion, van Dierendonck analyzed existing methodologies for assessing servant leadership, in addition to the antecedents and effects of servant leadership, based on the empirical data that is now available. In addition, he made recommendations for further study.

\section{Characteristics of a Servant Leader}

Greenleaf's concept of servant leadership is not precise, leaving room for interpretation and development, the most significant of which are the models established by Spears (1995), Laub (1999), Russell and Gregory Stone (2002), and Patterson (2003). Servant leaders exhibit traits such as being transparent and fair, adhering to friendship and honesty ideals, offering chances for professional growth, boosting business and corporate value, and instilling a feeling of trust in their workers (Adiguzel et al., 2020). Furthermore, according to Ehrhart (2004), servant leaders are empowering, relational, inclusive, moral, and balanced, and they place a high value on the growth and success of individuals while also paying attention to the business and the broader society. Ehrhart stated that servant leadership is comprised of seven primary areas of conduct, the most important of which are "forming relationships with subordinates, empowering subordinates, helping subordinates grow and succeed, behaving etbically, having conceptual skills, putting subordinates first, and creating value for those outside of the organization" (Ehrhart, 1998 as cited in Ehrhart, 2004, p. 73).

Spears (1995), one of the first writers to translate Greenleaf's concepts into a set of servant leadership attributes, identified ten criteria as fundamental components of servant leadership (pp. 15-17): "1. Listening (...) Servant-leaders must reinforce these important skills by making a deep commitment to listening intently to others. (...) Listening also encompasses getting in touch with one's own inner voice, and seeking to understand what one's body, spirit, and mind are communicating. (...) 2. Empathy (...) The most successful servant-leaders are those who have become skilled empathetic listeners. (...) 3. Healing (...) One of the great strengths of servantleadership is the potential for healing one's self and others. (...) 4. Awareness (...) General awareness, and especially self-awareness, strengthens the servant-leader. (...) 5. Persuasion (...) Servant-leaders seek to convince others, rather than coerce compliance. (...) 6. Conceptualization (...) The ability to look at a problem (or an organization) from a conceptualizing perspective means that one must think beyond day-to-day realities. (...) 7. Foresight (...) Foresight is a characteristic that enables servantleaders to understand the lessons from the past, the realities of the present, and the likely consequence of a decision for the future. It is deeply rooted within the intuitive mind. Thus, foresight is the one servantleader characteristic with which one may be born. (...) 8. Stewardship (...) Servant-leadership, like stewardship, assumes first and foremost a commitment to serving the needs of others. It also emphasizes 
the use of openness and persuasion, rather than control. (...) 9. Commitment to the growth of people (...) servant-leaders are deeply committed to the personal, professional, and spiritual growth of each and every individual within the institution (...) 10. Building community (...) servant-leaders seek to identify a means for building community among those who work within a given institution".

While the author acknowledges that these traits are not complete, he also failed to develop a model that distinguishes between the intrapersonal, interpersonal, and outcome dimensions of servant leadership, resulting in their inability to be effectively operationalized.

Numerous other writers added variants to these eleven features. For instance, Russell and Gregory Stone (2002) produced one of the most comprehensive models, identifying nine functional criteria of a servant leader: "Vision, Honesty, Integrity, Trust, Service, Modeling, Pioneering, Appreciation of others and Empowerment", and 11 accompanying characteristics: "Communication, Credibility, Competence, Stewardship, Visibility, Influence, Persuasion, Listening, Encouragement, Teaching and Delegation". Based on a thorough assessment of the literature, Laub (1999) identified six clusters of servant leadership traits that served as the foundation for his model of servant leadership.

Empowering individuals is a motivational construct that focuses on providing people with opportunities (Conger, 2017). According to servant leadership theory, servant leaders may encourage and assist their followers by empowering, prioritizing, and stimulating their maximum potential, hence advancing workers' job performance and involvement in creative activities (Liden et al., 2015). It demonstrates that the leader appreciates individuals and promotes personal growth (Laub, 1999). Encouraging self-directed decision-making and information sharing, as well as mentoring for creative performance, are all examples of empowering leadership conduct (Konczak et al., 2000). Servant leadership also enables workers to communicate their ideas in an evaluation atmosphere, fosters employee engagement, and rewards dependable performance, all of which predict different types of proactive behavior like an employee's number of awarded ideas (Frese et al., 1999). A person's intrinsic drive and higher creative performance, including idea implementation, are linked to the individual's empowerment, while team empowerment is linked to psychological empowerment, which predicts individual innovative behavior (Zhang and Bartol, 2010).

Authenticity is defined as the ability to express oneself in ways that are consistent with one's inner thoughts and feelings, and individuals achieve authenticity by aligning their inner selves, their privately held values, thoughts, and feelings, with their external displays of these in interactions with others (Harter, 2002). Authenticity is about being genuine to oneself and correctly portraying one's internal feelings, goals, and commitments both personally and publicly (Peterson \& Seligman, 2004). Because servant leadership places a premium on honesty and morality, it demonstrates dependability. From an organizational standpoint, authenticity may be described as acting in such a way that professional positions take a back seat to allow employees to act authentically as individuals (van Dierendonck, 2011). Genuine leaders make moral decisions freely and irrespective of possible normative or external societal influences (Guignon, 2004). 
54 | An introduction to servant leadership and its potential for nonprofit organizations

Another important attribute is bumility, which refers to the ability to put one's own successes and skills into correct perspective (Patterson, 2003). In some ways, humility may be defined as the willingness to perceive oneself honestly and to place oneself in context, to realize one's "insignificant part in a huge cosmos" (Morris et al., 2005, p. 1331). Serving leaders have the authority to see the advantages that may accrue to them from the expertise of their followers; in fact, they actively seek out the contributions of other people. Humility conveys a feeling of responsibility (Greenleaf \& Spears, 2014) for the people who are under the supervision of a leader. When it comes to modesty, humility is also important; after finishing a duty, a servant leader fades into the background. Having humility will make a leader more inclined to participate in activities like empowerment, listening, and perspective-taking, all of which have the ability to encourage employee initiative and participation (Liden et al., 2014).

Personal acceptance is described as the capacity to let go of perceived wrongdoings and refrain from carrying a grudge into subsequent circumstances. It also includes being able to understand and experience the feelings of others, as well as understanding where people are coming from (McCullough et al., 2001). There is a strong likelihood that followers will be more willing to try and learn from their errors if their leaders demonstrate qualities such as interpersonal acceptance and tolerance. It is critical for servant leaders to cultivate a culture of trust in which people feel welcomed, are allowed to make errors, and are certain that they will not be condemned for their actions (van Dierendonck, 2011).

Employees and the company both benefit from providing direction since it guarantees that individuals understand what they should be doing (Laub, 1999). A servant leader should make every effort to give guidance while also keeping the work dynamic and be tailored to the strengths and requirements of each follower. As part of giving guidance, it is also important to provide the appropriate level of responsibility, which has been identified as a significant characteristic of high-quality dyadic interpersonal relationships (van Dierendonck, 2011). When there is a substantial power gap between members of a team, the link between servant leadership and team effectiveness is not very strong. In this situation, team members are more likely to trust authoritative leaders and to depend on precise instructions from their leaders (Yang et al., 2017). It might also involve developing new techniques or ways of looking at existing issues while placing a strong emphasis on the principles and beliefs that guide one's activities (Russell \& Gregory Stone, 2002).

Stewardship is the desire to accept responsibility for the greater institution and to care for the needs of others instead of focusing on one's own interests and controlling others (Spears, 1995). Leaders should make a commitment to first and foremost serve the needs of others, with an emphasis on benefitting and serving the community. Leaders may encourage their followers to behave in the best interests of the company by providing a good example. Stewardship is directly associated with social duty, loyalty, and the ability to operate in a group. According to Peterson et al. (2012), stewardship may assist leaders to improve critical organizational outcomes by strengthening psychological ties, focusing on long-term goals, and caring about collective needs. 
Servant leaders demonstrate service-oriented actions in order to have a good impact on the lives of others, and they also have charitable and spiritual goals (Barbuto \& Wheeler, 2006). According to the findings of Adiguzel and colleagues (2020), having managers who take on a servant leadership position benefits workers and minimizes rule-breaking behavior. As a result, workers' job happiness improves when servant leadership decreases rule-breaking behavior.

Poor servant leaders are egotistical in their approach. When working in service contexts, they fail to demonstrate the altruistic and developmental orientations that are required. For example, they are unauthentic in front of their followers and do not invest in the long-term development of their subordinates' competence and talents. They also have less patience and tolerance for their adherents' misbehavior. As a result, their followers' ability to provide service declines. Good servant leaders provide timely help to their staff as they strive to achieve work objectives and learn new skills (Walumbwa et al., 2010).

In line with the aims of the vast majority of nonprofit organizations, servant leaders' characteristics are very well suited for the task. Servant leadership is one of the greatest leading styles a nonprofit manager could have in order to best serve the organization and its purpose.

\section{Servant leadership and other theories}

Servant leadership stands in stark contrast to other leadership models that are mainly concerned with boosting leaders' goals and primarily concerned with improving the financial performance of the firm (Eva et al., 2019). Chiniara and Bentein (2016) claimed that servant leadership, whose main goal is to meet workers' needs, innately understands and contributes to the fulfillment of the three fundamental psychological needs identified by self-determination theory. Thus, these writers demonstrated that the more a leader is seen as a servant, the more followers sense their fundamental psychological needs are satisfied.

Servant leadership inspires people to be more ethical and compassionate in their behaviors. In order to attain their goals, they go above and beyond the requirements of the assignment. A leader's reputation as a servant leader positively influences people's desire to participate in creative, nonconforming behaviors that create a new informal or formal norm for the reference group and display original, previously unexplored ideas, according to their study results (Brière et al., 2021).

Allen and his colleagues (2018) studied the relationship between servant leadership and organizational commitment, mediated through structural and psychological empowerment, finding that servant leaders empower organizational structures. Moreover, they find that employees in nonprofit organizations who are structurally empowered, are more likely to find their jobs challenging and enriching on a global scale, thus increasing their organizational commitment and increasing their level of information, resources, support, and opportunity for advancement. 
56 | An introduction to servant leadership and its potential for nonprofit organizations

Servant leadership, according to Bass (2000, p. 33), has some similar qualities with transformative leadership, including the need for "vision, influence, credibility, trust, and service but it goes beyond transformational leadership in selecting the needs of others as its highest priority". Additionally, Bass believed that the two leadership styles are strikingly comparable in terms of the transformational leadership characteristics of inspiring motivation and customized attention. A wide variety of organizationally relevant outcomes is predicted by servant leadership, which some researchers believe has "more promise as a stand-alone leadership" than transformative, genuine, and ethical leadership (Hoch et al., 2018, p. 502). Transformational leadership vs. servant leadership is a crucial difference, according to Gregory Stone et al. (2004). The primary focus of servant leadership is on others, whereas the primary focus of leaders who change organizations is on inspiring their employees to devote themselves to those organizations' aims and aspirations as well as achieving those goals themselves. Despite the conceptual parallels and contrasts between servant leadership and transformational leadership, this study investigates if there is a substantial empirical overlap between these two leadership styles in the workplace setting.

In contrast to other kinds of leadership that are centered on relationships and morality, servant leadership is built on relationships as it is a relationship-based approach to leadership. Service-oriented leadership varies from other types of leadership in that it places a greater emphasis on people and less on output. While other follower-focused types of leadership are clear about leaders' attention to people, they are less explicit about leaders' attention to productivity. Transformational leadership, despite the fact that it has a relational component, is mainly goal-oriented in the sense that it drives followers to go beyond their individual interests in order to accomplish communal objectives (Hoch et al., 2018).

When compared to transformational leaders, servant leaders demonstrate more regard and acceptance for their followers and subordinates. When seen through the eyes of their followers, servant leaders are regarded as knowledgeable and trustworthy service providers. As a result, servant leaders are more likely than transformational leaders to be seen as ingroup members by their followers since they embrace their followers rather than attempting to change them. Therefore, when servant leadership is shown, workers' effectiveness views are enhanced to a larger degree than when servant leadership is demonstrated (Chen et al., 2015).

Transformational management is classified as a leadership style that prioritizes the development of subordinates via individualized attention, intellectual stimulation, and supportive behavior (van Dierendonck, 2011). These components are very well related and complementary to servant leadership concepts. However, transformational leadership has a charismatic aspect, an idealized influence, which begs the issue of how followers evolve. The follower's progress is measured in terms of what is appropriate for the company and motivated by a desire to do better. Transformational leadership may exacerbate the issue of narcissism, in which a narrow emphasis on maximizing short-term profit may eventually result in long-term disaster (Giampetro-Meyer et al., 1998).

Freeborough and Patterson (2016) found a strong positive correlation between transformational leadership and employee engagement in a nonprofit setting, theirs 
being among the very few studies conducted in a nonprofit setting. Although most of the leadership research is based on for-profit organizations, there is still room for growth, especially with the rapid changes that we are seeing in the world, affecting all types of organizations.

\section{Acknowledgements}

$\mathrm{N} / \mathrm{A}$

\section{Funding}

The author received no financial support for the research, authorship, and/or publication of this article.

\section{Declaration of conflicting interests}

The author declares no conflicting interests.

\section{References}

Adiguzel, Z., Ozcinar, M. F., \& Karadal, H. (2020). Does servant leadership moderate the link between strategic human resource management on rule breaking and job satisfaction? European Research on Management and Business Economics, 26(2), 103-110. https://doi.org/10.1016/j.iedeen.2020.04.002

Akingbola, K. (2013). A Model of Strategic Nonprofit Human Resource Management. VOLUNTAS: International Journal of Voluntary and Nonprofit Organizations, 24(1), 214-240. https://doi.org/10.1007/s11266-012-9286-9

Allen, S., Winston, B. E., Tatone, G. R., \& Crowson, H. M. (2018). Exploring a model of servant leadership, empowerment, and commitment in nonprofit organizations. Nonprofit Management and Leadership, 29(1), 123-140. https://doi.org/ $10.1002 / \mathrm{nml} .21311$

Barbuto, J. E., \& Wheeler, D. W. (2006). Scale Development and Construct Clarification of Servant Leadership. Group \& Organization Management, 31(3), 300326. https://doi.org/10.1177/1059601106287091

Bass, B. M. (2000). The future of leadership in learning organizations. Journal of Leadership Studies, 7, 18-40.

Bauer, T. N., Perrot, S., Liden, R. C., \& Erdogan, B. (2019). Understanding the consequences of newcomer proactive behaviors: The moderating contextual role of servant leadership. Journal of Vocational Behavior, 112, 356-368. https://doi.org/10.1016/j.jvb.2019.05.001

Brière, M., Le Roy, J., \& Meier, O. (2021). Linking servant leadership to positive deviant behavior: The mediating role of self-determination theory. Journal of Applied Social Psychology, 51(2), 65-78. https://doi.org/10.1111/jasp.12716 
58 | An introduction to servant leadership and its potential for nonprofit organizations

Chen, Z., Zhu, J., \& Zhou, M. (2015). How does a servant leader fuel the service fire? A multilevel model of servant leadership, individual self identity, group competition climate, and customer service performance. Journal of Applied Psychology, 100(2), 511-521. https://doi.org/10.1037/a0038036

Chiniara, M., \& Bentein, K. (2016). Linking servant leadership to individual performance: Differentiating the mediating role of autonomy, competence and relatedness need satisfaction. The Leadership Quarterly, 27(1), 124-141. https://doi.org/10.1016/j.leaqua.2015.08.004

Conger, J. A. (2017). Motivate Performance through Empowerment. In E. A. Locke (Ed.), The Blackwell Handbook of Principles of Organizational Behaviour (pp. 143-155). Blackwell Publishing Ltd. https:/ / doi.org/10.1002/9781405164047.ch10

Ehrhart, M. G. (2004). Leadership and procedural justice climate as antecedents of unitlevel organizational citizenship behavior. Personnel Psychology, 57(1), 61-94. https://doi.org/10.1111/j.1744-6570.2004.tb02484.x

Eva, N., Robin, M., Sendjaya, S., van Dierendonck, D., \& Liden, R. C. (2019). Servant Leadership: A systematic review and call for future research. The Leadership Quarterly, 30(1), 111-132. https://doi.org/10.1016/j.leaqua.2018.07.004

Freeborough, R., \& Patterson, K. (2016). Exploring the effect of transformational leadership on nonprofit leader engagement. Servant Leadership: Theory \& Practice, 2(1), 49-70.

Frese, M., Teng, E., \& Wijnen, C. J. D. (1999). Helping to improve suggestion systems: Predictors of making suggestions in companies. Journal of Organizational Behavior, 20(7), 1139-1155. https://doi.org/10.1002/(SICI)1099-1379(199912)20:7<1139: AID-JOB946>3.0.CO;2-I

Giampetro-Meyer, A., Timothy Brown, S. J., Browne, M. N., \& Kubasek, N. (1998). Do We Really Want More Leaders in Business? Journal of Business Ethics, 17(15), 1727-1736. https://doi.org/10.1023/A:1006092107644

Greenleaf, R. K. (1977). Servant leadership: A journey into the nature of legitimate power and greatness. Paulist Press.

Greenleaf, R. K., \& Spears, L. C. (2014). The power of servant-leadership: Essays. BerrettKoehler Publishers.

Gregory Stone, A., Russell, R. F., \& Patterson, K. (2004). Transformational versus servant leadership: A difference in leader focus. Leadership \& Organization Development Journal, 25(4), 349-361. https://doi.org/10.1108/01437730410538671

Guignon, C. B. (2004). On being authentic (1st ed). Routledge.

Hale, J. R., \& Fields, D. L. (2007). Exploring Servant Leadership across Cultures: A Study of Followers in Ghana and the USA. Leadership, 3(4), 397-417. https://doi.org/10.1177/1742715007082964

Harter, S. (2002). Authenticity. In C. R. Snyder \& S. J. Lopez (Eds.), Handbook of positive psychology (pp. 382-394). Oxford University Press.

Herman, R. D. (2016). Executive Leadership. In D. O. Renz \& R. D. Herman (Eds.), The Jossey-Bass Handbook of Nonprofit Leadership and Management (pp. 167-187). John Wiley \& Sons, Inc. https://doi.org/10.1002/9781119176558.ch6

Hoch, J. E., Bommer, W. H., Dulebohn, J. H., \& Wu, D. (2018). Do Ethical, Authentic, and Servant Leadership Explain Variance Above and Beyond Transformational 
Leadership? A Meta-Analysis. Journal of Management, 44(2), 501-529. https://doi.org/10.1177/0149206316665461

Hu, J., \& Liden, R. C. (2011). Antecedents of team potency and team effectiveness: An examination of goal and process clarity and servant leadership. Journal of Applied Psychology, 96(4), 851-862. https://doi.org/10.1037/a0022465

Konczak, L. J., Stelly, D. J., \& Trusty, M. L. (2000). Defining and Measuring Empowering Leader Behaviors: Development of an Upward Feedback Instrument. Educational and Psychological Measurement, 60(2), 301-313. https://doi.org/10.1177/00131640021970420

Laub, J. (1999). Assessing the servant organization: Development of the Servant Organizational Leadership (SOLA) instrument. Dissertation Abstracts International, 60(2), 308.

Liden, R. C., Panaccio, A., Meuser, J. D., Hu, J., \& Wayne, S. J. (2014). Servant Leadership: Antecedents, Processes, and Outcomes. In D. V. Day (Ed.), The Oxford handbook of leadership and organizations (pp. 357-379). Oxford University Press.

Liden, R. C., Wayne, S. J., Meuser, J. D., Hu, J., Wu, J., \& Liao, C. (2015). Servant leadership: Validation of a short form of the SL-28. The Leadership Quarterly, 26(2), 254-269. https://doi.org/10.1016/j.leaqua.2014.12.002

Liden, R. C., Wayne, S. J., Zhao, H., \& Henderson, D. (2008). Servant leadership: Development of a multidimensional measure and multi-level assessment. The Leadership Quarterly, 19(2), 161-177. https:/ / doi.org/10.1016/j.leaqua.2008.01.006

Luthans, F., \& Avolio, B. (2003). Authentic leadership development. In K. S. Cameron \& J. E. Dutton (Eds.), Positive organizational scholarship (pp. 241-254). BerrettKoehler.

McCullough, M. E., Rachal, K. C., \& Hoyt, W. T. (2001). What we know (and need to know) about assessing forgiveness constructs. In M. E. McCullough, K. I. Pargament, \& C. E. Thoresen (Eds.), Forgiveness: Theory, research, and practice (Paperback ed). Guilford Press.

Morris, J. A., Brotheridge, C. M., \& Urbanski, J. C. (2005). Bringing humility to leadership: Antecedents and consequences of leader humility. Human Relations, 58(10), 1323-1350. https://doi.org/10.1177/0018726705059929

Palumbo, R. (2016). Challenging servant leadership in the nonprofit sector: The side effects of servant leadership. The Journal of Nonprofit Education and Leadership, 6(2), 81-98.

Patterson, K. A. (2003). Servant leadership: A theoretical model. [Doctoral Thesis]. Regent University.

Peterson, C., \& Seligman, M. E. P. (2004). Character strengths and virtues: A handbook and classification. American Psychological Association, Oxford University Press.

Peterson, S. J., Galvin, B. M., \& Lange, D. (2012). CEO Servant Leadership: Exploring Executive Characteristics and Firm Performance. Personnel Psychology, 65(3), 565596. https://doi.org/10.1111/j.1744-6570.2012.01253.x

Russell, R. F., \& Gregory Stone, A. (2002). A review of servant leadership attributes: Developing a practical model. Leadership \& Organization Development Journal, 23(3), 145-157. https://doi.org/10.1108/01437730210424 
60 An introduction to servant leadership and its potential for nonprofit organizations

Schaubroeck, J., Lam, S. S. K., \& Peng, A. C. (2011). Cognition-based and affect-based trust as mediators of leader behavior influences on team performance. Journal of Applied Psychology, 96(4), 863-871. https://doi.org/10.1037/a0022625

Sendjaya, S., \& Sarros, J. C. (2002). Servant Leadership: Its Origin, Development, and Application in Organizations. Journal of Leadership \& Organizational Studies, 9(2), 57-64. https://doi.org/10.1177/107179190200900205

Smith, B. N., Montagno, R. V., \& Kuzmenko, T. N. (2004). Transformational and Servant Leadership: Content and Contextual Comparisons. Journal of Leadership \& Organizational Studies, 10(4), 80-91. https://doi.org/10.1177/107179190401000406

Spears, L. C. (Ed.). (1995). Reflections on leadership: How Robert K. Greenleaf's theory of Servant-leadership influenced today's top management thinkers. J. Wiley.

van Dierendonck, D. (2011). Servant Leadership: A Review and Synthesis. Journal of Management, 37(4), 1228-1261. https://doi.org/10.1177/0149206310380462

van Dierendonck, D., Stam, D., Boersma, P., de Windt, N., \& Alkema, J. (2014). Same difference? Exploring the differential mechanisms linking servant leadership and transformational leadership to follower outcomes. The Leadership Quarterly, 25(3), 544-562. https://doi.org/10.1016/j.leaqua.2013.11.014

Walumbwa, F. O., Hartnell, C. A., \& Oke, A. (2010). Servant leadership, procedural justice climate, service climate, employee attitudes, and organizational citizenship behavior: A cross-level investigation. Journal of Applied Psychology, 95(3), 517-529. https://doi.org/10.1037/a0018867

Yang, J., Liu, H., \& Gu, J. (2017). A multi-level study of servant leadership on creativity: The roles of self-efficacy and power distance. Leadership \& Organization Development Journal, 38(5), 610-629. https://doi.org/10.1108/LODJ-10-2015-0229

Zhang, X., \& Bartol, K. M. (2010). Linking empowering leadership and employee creativity: The influence of psychological empowerment, intrinsic motivation, and creative process engagement. Academy of Management Journal, 53(1), 107-128. 